\title{
Surgical outcome and risk factors of bile duct injury repair following cholecystectomy
}

\author{
Factores de riesgo asociados a las complicaciones y a la falla terapéutica en las \\ reconstrucciones de lesiones de vía biliar secundarias a colecistectomía
}

\author{
Gustavo Martínez-Mier ${ }^{1,2 *}$, Héctor J. Luna-Ortiz³, Nicolás Hernández-Herrera ${ }^{3}$, Stefan Zilli-Hernandez² and \\ Francisco A. Lajud-Barquin ${ }^{2}$ \\ ${ }^{1}$ Transplantation and Hepatobiliary Surgery; ${ }^{2}$ Research Department; ${ }^{3}$ General Surgery Department. Unidad Médica de Alta Especialidad, Hospital \\ de Especialidades 14 Adolfo Ruiz Cortines, Instituto Mexicano del Seguro Social, Veracruz, Mexico
}

\begin{abstract}
Background: Bile duct injury during cholecystectomy is a serious complication. Multiple factors may alter their outcome. Method: We retrospectively evaluated our results following bile duct injury surgery repair and possible poor outcome risk factors from January 2008 to January 2017. Results: 58 patients (72.4\% female; mean age 41.8 years) were evaluated. $67.8 \%$ underwent open cholecystectomy as initial surgery. $79.3 \%$ of bile duct injury were diagnosed postoperative. Mean referral time was 9 weeks and early (< 1 week) repair was performed in 27.6\%. Most common lesion was Amsterdam type D (55.2\%) and Bismuth-Strasberg E4 (34.5\%). Morbidity was 39.6\%. Biliary leak occurred in 10.3\%, bilio-enteric stricture in $6.9 \%$ and recurrent cholangitis in $12.1 \%$, with $3 \%$ perioperative mortality. There was an $81 \%$ treatment success rate (McDonald classification). Risk factors for complications were: low hemoglobin, low albumin, low alkaline phosphatase, biliary stents and E-3-E5 lesions (univariate analysis only). Risk factors for treatment failure were previous repair outside our center, use of biliary stents and repair later than 1 week after lesion (univariate and multivariate analysis). Conclusions: Good efficacy and safety outcomes in bile repair surgery can be achieved in specialized centers. There are possible risk factors influencing outcomes that should be further validated.
\end{abstract}

Key words: Bile duct injury. Cholecystectomy. Surgical repair. Hepatojejunostomy. Complications. Outcome.

\section{Resumen}

Antecedentes: Las lesiones de vías biliares por colecistectomía son una complicación seria. Numerosos factores alteran el resultado de su reconstrucción. Método: Evaluación de la reconstrucción de lesiones de vía biliar y sus factores de riesgo (de enero de 2008 a enero de 2017). Resultados: Se evaluaron 58 pacientes (72.4\% mujeres; media de edad 41.8 años). El $67.8 \%$ tuvo colecistectomía laparoscópica como cirugía inicial. El 79.3\% se diagnosticó posoperatoriamente. La referencia promedio fue 9 semanas y su reparación temprana (< 1 semana) ocurrió en el 27.6\%. La lesión más común fue Amsterdam tipo D (55.2\%) y Bismuth-Strasberg E4 (34.5\%). La morbilidad fue del 39.6\% (fuga biliar 10.3\%, estenosis 6.9\% y colangitis recurrente12.1\%), con un $3 \%$ de mortalidad perioperatoria. Se logró un éxito del $81 \%$ de acuerdo con la clasificación de

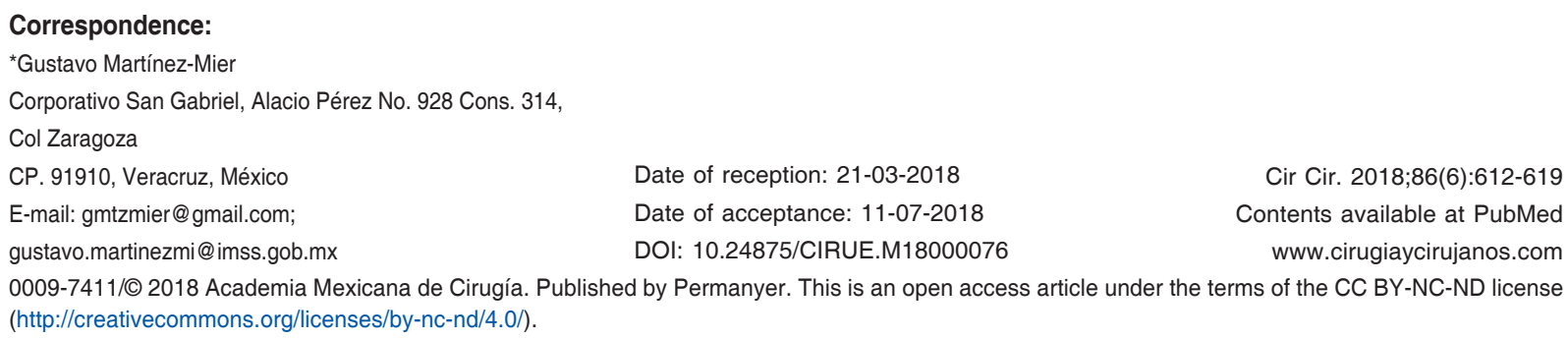

Cir Cir. 2018;86(6):612-619 Contents available at PubMed www.cirugiaycirujanos.com 0009-7411/@ 2018 Academia Mexicana de Cirugía. Published by Permanyer. This is an open access article under the terms of the CC BY-NC-ND license (http://creativecommons.org/licenses/by-nc-nd/4.0/). 
McDonald. Los factores de riesgo para las complicaciones fueron baja hemoglobina, baja albúmina, baja fosfatasa alcalina, tutores biliares y lesiones E3-E5 (análisis univariado). Los factores de riesgo para falla terapéutica fueron la reparación previa en otro centro, los tutores biliares y la reparación posterior a 1 semana tras la lesión (univariado y multivariado). Conclusión: Pueden obtenerse buenos resultados en las reconstrucciones de vías biliares en centros especializados. Existen algunos factores de riesgo para los resultados de las reconstrucciones que deben de ser validados.

Palabras clave: Lesión de vía biliar. Reconstrucción quirúrgica. Hepaticoyeyunostomía. Complicaciones. Resultados.

\section{Introduction}

Bile duct injuries (BDI) secondary to cholecystectomy are serious and complex complications. The incidence of $\mathrm{BDI}$ after a cholecystectomy, either conventional (CC) or laparoscopic (LC), varies from 0.3 to $1.4 \%$, depending on the criteria used for the injury and the study population ${ }^{1-3}$. BDls may have short- and long-term complications, cause prolonged hospital stays, require additional interventions and alter these patients' quality of life ${ }^{4,5}$.

BDls are a surgical challenge and their management requires the skills of hepatobiliary surgeons in referral centers ${ }^{6-9}$. Surgical technique refinement and advances in postoperative care have significantly decreased morbidity associated with BDI repair. However, BDI repair postoperative complications are still relatively common.

$\mathrm{BDI}$ repairs have successful results that range from $75 \%$ to $98 \%$ in large referral hospital centers ${ }^{10-19}$. Multiple factors can alter the results and complications of this type of procedures, including repair time, associated sepsis, vascular injury and the use of transanastomotic biliary stents ${ }^{10-16}$. Results and their complications can also be affected if patients were referred after a previous repair outside a tertiary care center ${ }^{17}$, or according to the time and the moment of referral ${ }^{10,17-22}$. Due to the above, we have decided to analyze our BDI repair results in order to identify the factors associated with our complications and their success.

\section{Method}

A retrospective review of the records of patients who suffered a BDI and were referred to our unit from January 2008 to January 2017 was carried out. The study was previously approved by the local ethics and research committee of the unit. Repairs subsequent to total or major sections of the common bile duct, common liver duct or major segmental ducts were included in the study. Repairs for benign stricture after cholecystectomy with or without bile duct exploration were also included. Cystic duct and vesicular fossa minor bile leaks well as chronic pancreatitis-secondary stricture and malignancy, biliary lithiasis, Oddi sphincter stricture and primary sclerosing cholangitis.

\section{Data and preoperative management}

Patient demographic and laboratory data were recorded, in addition to initial procedure (CC, LC or both) and the timing of injury diagnosis (transoperative or postoperative). Among the data to be recorded, whether the patient had had a previous repair outside the unit or not was determined. Referral timing was recorded, and repair time was defined as early if it was performed during the first week after BDI or as intermediate if it was carried out in less than 6 weeks after the BDI. Whether the repair was carried out during the same admission for initial surgery was also recorded.

\section{BDI classification}

BDIs were classified according to the Amsterdam Academic Medical Center classification ${ }^{23}$, and the level of the injury was determined using Bismuth-Strasberg combined classification ${ }^{24,25}$ (Table 1).

\section{Surgical management}

Patients underwent BDI repair when the following conditions were met: 1) absence of biloma (documented by imaging techniques, either ultrasound or tomography); 2) biliary anatomy adequate identification by means of cholangiography by magnetic resonance imaging or cholangiopancreatography; and 3) absence of sepsis, cholangitis or organ failure.

Standard surgical treatment consisted of an end-toside hepaticojejunostomy by cephalic dissection until bile ducts of macroscopically healthy appearance were obtained. The hiliar plate was divided when necessary. Intrahepatic anastomosis was performed by segment IV partial resection if extrahepatic bile ducts 
Cirugía y Cirujanos. 2018;86(6)

Table 1. Classification of bile duct injuries

\begin{tabular}{|c|c|c|c|}
\hline \multicolumn{2}{|c|}{ Amsterdam Academic Medical Center } & \multicolumn{2}{|c|}{ Bismuth-Strasberg } \\
\hline Type & Description & Type & Description \\
\hline A & $\begin{array}{l}\text { Cystic duct leaks or leakage from aberrant or peripheral } \\
\text { hepatic duct }\end{array}$ & E1 & $\begin{array}{l}\text { Common hepatic duct division/ stricture more than } 2 \mathrm{~cm} \\
\text { from bifurcation }\end{array}$ \\
\hline B & $\begin{array}{l}\text { Major bile duct leaks with or without concomitant biliary } \\
\text { strictures }\end{array}$ & E2 & $\begin{array}{l}\text { Common hepatic duct division/ stricture less than } 2 \mathrm{~cm} \\
\text { from bifurcation }\end{array}$ \\
\hline C & Bile duct strictures without bile leakage & E3 & Common bile duct division/ stricture at bifurcation \\
\hline \multirow[t]{2}{*}{$\mathrm{D}$} & $\begin{array}{l}\text { Complete transection of the duct with or without } \\
\text { excision of some portion of the biliary tree }\end{array}$ & E4 & $\begin{array}{l}\text { Hilar stricture/division with involvement of confluence and loss of } \\
\text { communication between right and left hepatic duct }\end{array}$ \\
\hline & & E5 & $\begin{array}{l}\text { Aberrant right hepatic duct with concomitant stricture of the } \\
\text { common hepatic duct }\end{array}$ \\
\hline
\end{tabular}

were not identified. All anastomoses were performed with 4-0 or 5-0 absorbable monofilament suture ${ }^{26}$. At the surgeon's opinion, Silastic ${ }^{\circledR}$ transhepatic stents (8 $\mathrm{Fr}$ ) were inserted through the lumen of the duct, exteriorized through the liver and abdominal wall with the distal tip in intestinal lumen. In some others cases, these stents were only placed through the anastomosis without externalizing through the liver or jejunal loop. The jejunal loop was anastomosed in a side-end modality to the jejunum at $40-60 \mathrm{~cm}$ of hepaticojejunostomy and at a similar distance from the ligament of Treitz as standard. Two closed drains were placed at the site of anastomosis, which were maintained until absence of biliary leak after patient oral ingestion was documented. In the case of transhepatic stents, these were left for external drainage until the absence of biliary leakage after patient oral ingestion. They were closed and removed one month later.

\section{Follow-up and results}

Inpatient complications, length of stay and in-hospital mortality were recorded. Patients were followed-up on an outpatient basis and stratified according to the McDonald classification for BDI repair results ${ }^{27}$. This classification uses liver function tests, clinical symptoms and invasive procedures. Grades A and B are considered as satisfactory treatment. For analysis purposes, patient follow-up was divided into: 1) patients with less than 1-year follow-up; 2) patients with between 1 and 5 years of follow-up; and 3) patients with more than 5 years' follow-up. It was also divided according to median patient follow-up and by stages: from the beginning of the study to September 2013 and from September 2013 to the last patient included in the study.

\section{Statistical analysis}

Continuous variables are described as the mean, standard deviation and range, and categorical variables as frequencies and percentages. To identify the factors associated with biliary complications and with therapeutic failure, a univariate analysis was performed using Student's t-test or Mann-Whitney's Utest if continuous variables were parametric or non-parametric, respectively. The chi-square test was used or Fisher's exact test, or both, for the univariate analysis of categorical variables. A multivariate analysis was performed by binary logistic regression for the variables that were statistically significant in the univariate analysis. A p-value $<0.05$ was considered statistically significant. For statistical analysis, the SPSS software, version 21, was used.

\section{Results}

\section{Patient characteristics and presentation}

Fifty-eight patients were included in the study. Mean age was $41.8 \pm 14.7$ years (range: $14-79$ years). There were 42 female patients $(72.4 \%)$ and 16 male patients (27.6\%). CC was more common (37 patients, $63.8 \%$ ) than LC (21 patients, 36.2\%). Most BDIs (46, 79.3\%) were diagnosed in the postoperative period. After initial cholecystectomy, 17 patients (29.3\%) underwent a second surgery, and 8 patients (13.8\%), had two surgeries. Four patients $(6.9 \%)$ underwent repair of their $\mathrm{BDI}$ prior to their referral; average time for referral was $9.1 \pm 33$ weeks (range: 0-250 weeks), with a median of 3 weeks. Sixteen patients (27.6\%) underwent early BDI repair ( $<1$ week) after having sustained it, and 
45 patients $(77.6 \%)$ had it practiced in an intermediate form ( $<6$ weeks). Thirty-seven patients $(63.8 \%)$ underwent BDI repair at same admission for initial surgery.

Laboratory tests at admission showed a mean hemoglobin of $11.2 \pm 2 \mathrm{~g} / \mathrm{dL}$ (range: $6.9-16.1 \mathrm{~g} / \mathrm{dL}$ ), with a leukocyte average of $10.6 \pm 4.5$ cells $/ \mathrm{mm}^{3}$ (range: 3.225.2 cells $/ \mathrm{mm}^{3}$ ). Twenty-one patients $(36.2 \%)$ had jaundice with total serum bilirubin $>2.5 \mathrm{mg} / \mathrm{dL}$, with an average of $3.8 \pm 5.1 \mathrm{mg} / \mathrm{dL}$ (range: $0.2-21.5 \mathrm{mg} / \mathrm{dL}$ ). Average serum albumin was $3.2 \pm 0.4 \mathrm{~g} / \mathrm{dL}$ (range: 2.1 $4.4 \mathrm{~g} / \mathrm{dL}$ ), and 22 patients (37.9\%) had a serum albumin $<3 \mathrm{~g} / \mathrm{dL}$ at the time of their referral. Average alkaline phosphatase was $327 \pm 258 \mathrm{IU} / \mathrm{L}$ (range: $37-1036 \mathrm{IU} / \mathrm{L}$ ), and 46 patients $(79.2 \%)$ had an alkaline phosphatase higher than our laboratory normal range (129 IU/L).

Eleven patients (19\%) were classified as having type $B$ injuries according to Amsterdam classification, 15 patients $(25.9 \%)$, as type C, and 32 patients $(55.2 \%)$, as type D. All had Bismuth-Strasberg classification type E injuries: $6(10.3 \%)$, type E1; $18(31 \%)$, type E2; $12(20.7 \%)$, of type E3; 20 (34.5\%), type E4; and 2 (3.4\%), type E5. Thirty-four patients (58.6\%) had highgrade injuries (E3-E5) and 20 (34.5\%) lost hepatic ducts confluence.

\section{Surgery and results}

In 51 patients $(88 \%)$, repair was carried out with a side-to-end hepaticojejunostomy. Five patients (8.6\%) had two separated liver anastomoses, and 2 patients (3.4\%), underwent an intrahepatic hepatojejunostomy. In 27 repairs (46.6\%), stents were used, with 11 (19\%) being transhepatic. Average hospital days of stay was $25.2 \pm 18.4$ (range: $6-100$ days).

Twenty-three patients (39.6\%) suffered at least one in-hospital complication. Complications were divided into non-biliary and biliary. The most common nonbiliary complication was wound infection, in 10 patients $(17.2 \%)$, followed by enterocutaneous fistula in four patients $(6.8 \%)$ and post-incisional hernia also in four patients $(6.8 \%)$. Only one patient $(1.7 \%)$ developed pneumonia and another had liver failure, which had fatal outcomes (mortality of $3.2 \%$ ).

The most common in-hospital biliary complication was cholangitis in 11 patients (19\%), followed by bile leak in 6 patients (10.3\%). Four patients $(6.9 \%)$ developed postoperative stricture (at 2, 12, 18 and 70 months, respectively) and 7 (12.1\%) presented recurrent cholangitis (more than two episodes during follow-up).
Table 2. McDonald classification for long-term results after bile duct injury repair

\begin{tabular}{llc}
\hline Grade & Description & $\mathbf{n}(\%)$ \\
\hline A & Normal liver function tests - No symptoms & $35(60.3)$ \\
B & Liver function tests slightly altered - No symptoms & $12(20.7)$ \\
C & Abnormal liver function tests - Cholangitis and pain & $6(10.3)$ \\
D & $\begin{array}{l}\text { Endoscopic or surgical examination } \\
\text { (perioperative death) }\end{array}$ & $5(8.6)$ \\
\hline
\end{tabular}

\section{Follow-up}

Fifty-six patients were followed-up on an outpatient basis for an average of $29.8 \pm 27.3$ months (median: 23 months; range: 1-96 months). Of the four patients $(6.9 \%)$ who developed strictures, two underwent repair examination surgery and the other two underwent percutaneous intrahepatic stent placement. Two patients (3.2\%) developed liver cirrhosis. The degree of success was staged according to the McDonald classification, as grade $A$ and $B$, in 47 patients (81\%) (Table 2). Twenty-seven patients $(48.2 \%)$ had a follow-up of between 1 and 5 years, 21 patients (37.5\%) had a follow-up $<1$ year and 8 patients $(14.2 \%)$ had a follow-up $>5$ years. There were no significant differences between patients who underwent surgery prior to September 2013 and those who were operated later in terms of biliary complications and therapeutic success. Patients with a follow-up $>5$ years had a higher rate of recurrent cholangitis and lower therapeutic success than those with a follow-up $<5$ years $(p<0.05)$. Patients with a follow-up $>23$ months had lower therapeutic success than those with a follow-up $<23$ months $(p<0.05)$. These results are shown in table 3.

\section{Risk factors associated with BDI repair complications}

Univariate and multivariate analysis of those patients with long-term follow-up was carried out in order to identify possible risk factors associated with BDI repair biliary complications. Patients with biliary complications had lower hemoglobin, albumin and alkaline phosphatase values than those without biliary complications. These differences were statistically significant $(p<0.05)$. Biliary complications also occurred with more frequency in patients who had higher grade injuries according to Bismuth-Strasberg 
Table 3. Long-term biliary complications and bile duct injury successful repair results according to McDonald's classification

\begin{tabular}{|c|c|c|c|c|c|c|}
\hline Follow-up time & Stricture $(n) \%$ & $p$ & Recurrent cholangitis ( $\mathrm{n} \%$ ) & $\mathrm{p}$ & Success (McDonald A/B) ( $n \%)$ & $\mathrm{p}$ \\
\hline \multicolumn{7}{|l|}{ Date of surgery } \\
\hline Before 09/2013 $(n=28)$ & (2) 7.1 & & (5) 17.8 & & (22) 78.5 & \\
\hline After 09/2013 $(n=28)$ & (2) 7.1 & 0.5 & (1) 3.6 & 0.09 & (26) 85.7 & 0.1 \\
\hline \multicolumn{7}{|l|}{ Follow-up time } \\
\hline$<1$ year $(n=21)$ & (1) 4.7 & & (0) 0 & & (21) 100 & \\
\hline $1-5$ years $(n=27)$ & (2) 14.8 & & (1) 7.4 & & (23) 85.2 & \\
\hline$>5$ years $(n=8)$ & (1) 12.5 & 0.1 & (5) 50 & $0.001^{*}$ & (4) 50 & $0.003^{*}$ \\
\hline \multicolumn{7}{|l|}{ Average follow-up (median) } \\
\hline$<23$ months $(n=27)$ & $(2) 7.4$ & & (0) 0 & & (26) 96.3 & \\
\hline$>23$ months $(n=28)$ & (2) 6.8 & 0.1 & (6) 20.7 & $0.001^{*}$ & (22) 75.9 & $0.03^{*}$ \\
\hline
\end{tabular}

Table 4. Univariate/multivariate analysis of factors associated with biliary complications in the repair of bile duct injuries

\begin{tabular}{|c|c|c|c|c|}
\hline \multirow[t]{2}{*}{ Factors } & Univariate & \multirow[t]{2}{*}{$\mathrm{p}$} & Multivariate & \multirow[t]{2}{*}{$p$} \\
\hline & Media \pm Odds Ratio $(95 \% \mathrm{Cl})$ & & Exp (B) Odds Ratio (95\% Cl) & \\
\hline \multicolumn{5}{|l|}{ Hemoglobin (g/dL) } \\
\hline $\begin{array}{l}\text { Complication } \\
\text { No complication }\end{array}$ & $\begin{array}{l}10.4 \pm 1.6 \\
11.6 \pm 2.0\end{array}$ & $0.03^{*}$ & $0.04(-0.04-0.13)$ & 0.3 \\
\hline \multicolumn{5}{|l|}{ Albumin (g/dL) } \\
\hline Complication & $2.9 \pm 0.5$ & $0.04^{*}$ & $0.1(-0.42-0.46)$ & 0.9 \\
\hline No complication & $3.4 \pm 0.6$ & & & \\
\hline Albumin $<3(\mathrm{~g} / \mathrm{dL})$ & $3.06(1.1-8.3)$ & $0.02^{\ddagger}$ & $0.2(-0.27-0.79)$ & 0.3 \\
\hline \multicolumn{5}{|l|}{ Alkaline phosphatase (IU/L) } \\
\hline Complication & $209.2 \pm 130$ & $0.009^{\dagger}$ & $0(-0.001-0.001)$ & 0.6 \\
\hline No complication & $406.3 \pm 292$ & & & \\
\hline Alkaline phosphatase < $129 \mathrm{IU} / \mathrm{L}$ & $2.1(0.81-5.43)$ & $0.04^{\ddagger}$ & $-0.2(-0.68-0.2)$ & 0.2 \\
\hline Bismuth Strasberg III-V injuries & $1.4(1.04-2.11)$ & $0.03^{\ddagger}$ & $-0.06(-0.4-0.27)$ & 0.6 \\
\hline Transanastomotic stents & $3.2(1.32-7.82)$ & $0.004^{\ddagger}$ & $0.33(-0.046-0.71)$ & 0.08 \\
\hline
\end{tabular}

*Statistically significant by Student's t-test.

†Statistically significant by Mann-Whitney's U-test.

¥Statistically significant by chi-square test.

$\mathrm{Cl}$ : Confidence interval.

classification (E3-E5) and in those in whom anastomotic stents were used. These differences were also statistically significant $(p<0.05)$ (Table 3$)$. The multivariate logistic regression analysis showed no statistically significant differences between the statistically significant variables in the univariate analysis (Table 4).

\section{Risk factors associated with BDI repair failure}

Univariate and multivariate analysis of those patients with long-term follow-up was carried out in order to identify possible risk factors associated with BDI repair success or therapeutic failure. The univariate analysis showed that patients with therapeutic success (McDonald grade A and B) were those without a previous repair attempt, those who underwent BDI early repair ( $<1$ week) and those in whom stents were not used. These differences were statistically significant $(p<0.05)$ (Table 5). The multivariate logistic regression analysis confirmed that previous repair and stent use were risk factors for BDI repair therapeutic failure $(p<0.05)$. BDI early repair showed a trend towards statistical significance, without reaching it (Table 4). 
Table 5. Univariate/multivariate analysis of factors associated with bile duct lesion repair therapeutic failure

\begin{tabular}{|c|c|c|c|c|}
\hline \multirow[t]{2}{*}{ Factors } & Univariate & \multirow[t]{2}{*}{ p } & Multivariate & \multirow[t]{2}{*}{$\mathrm{p}$} \\
\hline & Odds Ratio $(95 \% \mathrm{Cl})$ & & Exp (B) Odds Ratio (95\% Cl) & \\
\hline Previous repair (no) & $6.5(2.5-16.6)$ & $0.01^{*}$ & $-0.503(-0.834-0.171)$ & $0.004^{\dagger}$ \\
\hline Repair in $>1$ week & $1.329(1.09-1.52)$ & $0.036^{\dagger}$ & $0.172(-0.015-0.358)$ & 0.07 \\
\hline Transanastomotic stents & $9.9(1.32-74.1)$ & $0.005^{*}$ & $-0.242(-0.411-0.073)$ & $0.006^{\dagger}$ \\
\hline
\end{tabular}

*Statistically significant by Fisher's exact test.

†Statistically significant by binary logistic regression.

$\mathrm{Cl}$ : confidence interval.

\section{Discussion}

The results of this study indicate that our center has a good BDI repair success rate, although this success decreases as follow-up time exceeds 5 years. In addition, we found that there are risk factors related to complications and repair success, such as patient general status, type of injury, use of anastomotic stents, lesion repair time and previous repair attempts prior to referral to our unit.

BDI repair main purpose is to achieve adequate biliary excretion without causing postoperative symptoms or liver function disorders. Since Lillemoe et al. ${ }^{6}$ and de Sicklick et al. ${ }^{7}$ publications, where BDI repair success (categorized as asymptomatic with normal or slightly altered liver function tests) was $90.8 \%$, the therapeutic success has been described within a range that goes from $75^{9}$ to $93 \%{ }^{11}$, with intermediate figures ${ }^{15}$. BDI repair efficacy and safety includes biliary-origin morbidity and overall morbidity. BDI repair complication rate is 15 to $43 \% \%^{7,9,13,16,18}$ in specialized hepatobiliary centers, and it increases to almost $75 \%$ in hospitals where there are no hepatobiliary specialists $^{16}$. An incidence of postoperative biliary leakage of $5 \%$ has been described ${ }^{7}$, cholangitis (postoperative or recurrent) in 5-27\%,16 and bilioenteric stricture in $5-10 \%{ }^{7,12}$. Some centers have managed to reduce the incidence of cholangitis and stricture from $11 \%$ to $6 \%$ and from $13 \%$ to $5 \%$, respectively, as they have grown as referral centers and have gained more experience in the management of these cases ${ }^{18}$; and except for some cases of mortality higher than $6 \%{ }^{11}$, it is close to $2 \%, 8$. Our center has managed to obtain a good success rate, of $81 \%$, according to McDonald's classification throughout the follow-up, similar and higher than $75 \%$ according to the date of surgery (before or after 2013) and in patients with follow-up longer or shorter than 2 years approximately (76 vs. 93\%), despite this difference being statistically significant. We have also been able to achieve adequate efficacy and safety (morbidity of $39 \%: 12-19 \%$ cholangitis [postoperative and recurrent], $10 \%$ bile leak and $6 \%$ stricture), with a mortality of $3 \%$ in a myriad of patients with complex lesions (Amsterdam grade $B$ and $D$ ) and biliary hilum high sections or strictures (BismuthStrasberg E3-E5 lesions). Both stricture and recurrent cholangitis remained at effective and safe percentages according to the time periods on follow-up, except for the incidence of cholangitis in patients who were followed for more than 5 years. BDI repair prolonged follow-up allows evaluating the absence of biliary stricture (goal of success in these cases). Stricture can occur at different procedural intervals, up to 7 years after its performance ${ }^{5,7}$. Some authors consider between 2 and 5 years to be an adequate followup goal ${ }^{14}$, and others prolong it to up to 20 years ${ }^{20}$. Therefore, we follow our patients for the longest possible time to make sure therapeutic success prevails. Furthermore, long-term patient follow-up allows establishing growth and experience curves, as described in programs that have achieved an increase in referrals ${ }^{8}$, and in selected cases to evaluate the assessment of liver damage that may exist prior to repair ${ }^{22}$.

Despite being a standardized technique, we found that the use of stents in hepatic anastomosis (transhepatic or not) was a risk factor associated with biliary complications in the univariate analysis, and with therapeutic failure both in the multivariate and univariate analysis. For their use, we follow previously published recommendations ${ }^{15,22}$ (ischemic or scarred tissue with fibrosis and < 4-mm diameter tubes), and like others, complications are lesser when they are not used.

Hepatobiliary specialists have tried to identify possible risk factors related to complications or to unsatisfactory results after BDI repair. Different studies have described that repairs not performed by 
hepatobiliary surgeons increase the risk of general and biliary complications, as well as of therapeutic failure ${ }^{11,16,17,20,22}$. High injuries have also been associated with complications, especially with cholangitis ${ }^{11,12,17}$. We found similar results regarding the level of the injury and the use of stents, as previously mentioned, in addition to other factors such as low preoperative values of albumin, hemoglobin and alkaline phosphatase. Although hypoalbuminemia had already been referred to as a factor associated with $\mathrm{BDI}$ repair complications ${ }^{28}$, low hemoglobin and alkaline phosphatase have not been related to complications after $\mathrm{BDI}$. We might suggest hemoglobin as a surrogate marker of sepsis and inflammation, conditions that should be avoided for a successful BDI repair 14,15,17,22,28; however, we found no relationship with alkaline phosphatase values in the development of complications. It should be noted that none of these associations had statistical significance in the multivariate analysis, similar to what has been observed in other studies ${ }^{11,13}$.

In addition to trying to predict complications, it is of the highest relevance being able to predict success in the long-term follow-up of BDI repair. We found that a repair prior to referral to our center and the use of stents are associated with and are a risk factor for therapeutic failure, and that early repair is associated with treatment success. Repair timing has been a subject of debate, since some suggest that the repair should be late when performed by hepatobiliary surgeons ${ }^{11,12}$ and others describe that repair timing matters if it is carried out by non-hepatobiliary surgeons ${ }^{17}$. Furthermore, late repair may be accompanied by vasculobiliary injuries and previous endoscopic procedures that overcloud treatment success ${ }^{21}$. This combination of factors supports the fact that previous repair, especially if not performed in a referral center, confers a higher risk of therapeutic failure ${ }^{13,22}$. Stents association not only with complications, but also with success, justifies their selective use $\mathrm{e}^{15,22}$.

Although our study has good postoperative results and confirms risk factors for therapeutic failure in BDI repairs, we must recognize that the described findings arise from a retrospective series with a not too large sample, and that we have not yet standardized biliary imaging studies and biliary vascular evaluation, as mentioned in the methods, and that, therefore, these shortfalls could negatively affect our study.

In summary, DBI repair should be carried out in a way that is effective and safe. There are possible risk factors associated with repair failure, such as previous repair outside a referral center, use of anastomotic stents and repairs that are not performed early. Some perioperative factors, such as hemoglobin, albumin and alkaline phosphatase values, in addition to level of the injury and use of stents, can be associated with biliary complications of these repairs. These findings must be confirmed by having a higher number of referrals of this pathology to our center and with a longer term follow-up.

\section{Conflict of interests}

None to declare.

\section{Funding}

None.

\section{References}

1. Gouma DJ, Go PM. Bile duct injury during laparoscopic cholecystectomy and conventional cholecystectomy. J Am Coll Surg. 1994;178:229-33.

2. Massarweh NN, Devlin A, Symons RG, Broeckel JA, Flum DR. Risk tolerance and bile duct injury: surgeon characteristics, risk-taking preference, and common bile duct injuries. J Am Coll Surg. 2009;209:17-24.

3. Tantia O, Jain M, Khanna S, Sen B. latrogenic biliary injury: 13,305 cholecystectomies experienced by a single surgical team over more than 13 years. Surg Endosc. 2008;22:1077-86.

4. Flum DR, Cheadle A, Prela C, Dellingwer EP, Chan L. Bile duct injury during cholecystectomy and survival in Medicare beneficiaries. JAMA. 2003;290:2168-73.

5. Ejaz A, Spolverato G, Kim Y, Dodson R, Sicklick JK, Pitt HA, et al. Longterm health-related quality of life after iatrogenic bile duct injury repair. J Am Coll Surg. 2014;5:923-32.

6. Lillemoe KD, Melton GB, Cameron JL, Pitt HA, Campbell KA, Talamini MA, et al. Postoperative bile duct strictures: management and outcome in the 1990s. Ann Surg. 2000;232:430-41.

7. Sicklick JK, Camp MS, Lillemoe KD, Melton GB, Yeo CJ, Campbell KA et al. Surgical management of bile duct injuries sustained during laparoscopic cholecystectomy. Perioperative results in 200 patients. Ann Surg. 2005;241:786-95.

8. Mercado MA, Franssen B, Domínguez I, Arriola JC, Ramírez F, Elnecavé $A$, et al. Transition from a low-to a high-volume centre for bile duct repair: changes in technique and improved outcome. HPB. 2011;13:767-73.

9. Nuzzo G, Giuliante F, Giovannini I, Murazio M, D'Acapito F, Ardito F, et al. Advantages of multidisciplinary management of bile duct injuries during cholecystectomy. Am J Surg. 2008;195:763-9.

10. Stewart L, Way LW. Laparoscopic bile duct injuries: timing of surgical repair does not influence success rate. A multivariate analysis of factors influencing surgical outcomes. HPB. 2009;11:516-22.

11. Schmidt SC, Langrehr JM, Hintze RE, Neuhaus P. Long-term results and risk factors influencing outcome of major bile duct injuries following cholecystectomy. Br J Surg. 2005;92:76-82.

12. Walsh RM, Henderson JM, Vogt DP, Brown N. Long-term outcome of biliary reconstruction for bile duct injuries from laparoscopic cholecystectomies. Surgery. 2007;142:450-7.

13. Pottakkat B, Vijayahari R, Prakash A, Singh RK, Behari A, Kapoor VK, et al. Factors predicting failure following high bilio-enteric anastomosis for post-cholecystectomy benign biliary strictures. J Gastrointest Surg. 2010;14:1389-94.

14. Huang Q, Yao HH, Shao F, Wang C, Hu YG, Hu S, et al. Analysis of risk factors for postoperative complication of repair of bile duct injury after laparoscopic cholecystectomy. Dig Dis Sci. 2014;59:3085-91.

15. Mercado MA, Chan C, Orozco H, Cano G, Chaparro JM, Galindo E, et al. To stent or not to stent bilioenteric anastomosis after iatrogenic injury. A dilemma not answered? Arch Surg. 2002;137:60-3.

16. Mercado MA, Vilatoba M, Contreras A, Leal P, Cervantes E, Arriola JC, et al. latrogenic bile duct injury with loss of confluence. World J Gastrointest Surgery. 2015;7:254-60. 
17. Perera MT, Silva MA, Hegab B, Muralidharan V, Branhall SR, Mayer AD, et al. Specialist early and intermediate repair of post-laparoscopic cholecystectomy bile duct injuries is associated with an improved long-term outcome. Ann Surg. 2011;253:553-60.

18. Fisher CP, Fahy BN, Aloia TA, Bass BL, Gaber O, Ghobrial RM. Timing of referral impacts surgical outcomes in patients undergoing repair of bile duct injuries. HPB. 2009;11:32-7.

19. DeReuver PR, Grossmann I, Busch OR, Obertop H, van Gulik TM Gouma DJ. Referral pattern and timing of repair are risk factors for complications after reconstructive surgery for bile duct injury. Ann Surg. 2007;245:763-70.

20. Patrono D, Benvenga R, Colli F, Baroffio P, Romagnoli R, Salizzoni M Surgical management of post-cholecystectomy bile duct injuries: referral patterns and factors influencing early and long-term outcome. Updates Surg. 2015;67:283-91.

21. Kirks RC, Barnes TE, Lorimer PD, Cochran A, Siddiqui I, Martine JB, et al. Comparing early and delayed repair of common bile duct injury to identify clinical drivers of outcome and morbidity. HPB. 2016; 18:718-25.
22. Domínguez I, Sanford DE, Liu J, Hawkins WG, Mercado MA. Timing of surgical repair after bile duct injuries impact postoperative complications but not anastomotic patency. Ann Surg. 2016;264:544-53.

23. Neuhaus P, Schmidt SC, Hintze RE, Adler A, Veltzke W, Raakow R, et al. Classification and treatment of bile duct lesions following laparoscopic cholecystectomy. Chirurg. 2000;71:166-73.

24. Bismuth $H$, Majno PE. Biliary strictures: classification based on the principles of surgical treatment. World J Surg. 2001:25:1241-4.

25. Strasberg S, Hertl M, Soper N. An analysis of the problem of biliary injury during laparoscopic cholecystectomy. J Am Coll Surg. 1995; 180:101-25

26. Clavien $P$, Sarr MG, Fong Y. Atlas of upper gastrointestinal and hepato-pancreato-biliary surgery. Berlin Heidelberg: Springer-Verlag; 2007.

27. McDonald ML, Farnell MB, Nagorney DM, Ilstrup DM, Kutch JM. Benign biliary strictures: repair and outcome with a contemporary approach. Surgery. 1995;118:582-90.

28. Mercado MA, Chan C, Orozco H, Podgaetz E, Porras DE, De la Medina AR, et al. Low serum albumin is not a contraindication for early iatrogenic bile duct injury repair. Ann Hepatol. 2005;4:184-7. 